Научная статья /

Research Article

УДК 821.І6г.I.0+398.I

ББК $83.3(2 \mathrm{Poc}=\mathrm{Pyc}) 6+82.3$
«КИРГИЗСКАЯ СКАЗКА» В «ДАРЕ»: НАБОКОВ, ФОЛЬКЛОР И ОРИЕНТАЛИЗМ

Аннотация: Во второй главе романа «Дар», заново переживая последнее прощание с погибшим или пропавшим без вести отцом, Федор Константинович ГодуновЧердынцев вспоминает «киргизскую сказку» о ненасытном человеческом глазе. Сюжет этой истории восходит к талмудической притче об Александре Македонском, которая несколько раз публиковалась и пересказывалась на русском языке в XIX - начале XX вв. Вместе с тем кажется маловероятным, что Набоков использовал в своем романе фольклорный текст, действительно бытовавший в Центральной Азии. По всей видимости, «киргизская сказка» из романа «Дар» непосредственно восходит к одной или нескольким русским версиям этого сюжета XIX - начала XX вв. При этом вариант Набокова включает в себя ряд международных сказочных, а также литературных мотивов и, вероятно, написан с оглядкой на «калмыцкую сказку» из «Капитанской дочки», а также на русскую стихотворную сказку первой половины XIX в. Хотя центральной темой набоковской притчи остается ненасытность зрения и бренность человеческой жизни, ее кон- и подтексты указывают на ряд других значимых тем романа: смерти и бессмертия, поисков земного рая, закрытых дверей и изгнания, источников любви и поэтического вдохновения. Ориенталистский колорит сказки (и соответствующей главы романа в целом) представляет собой литературную игру с ограниченным кругом претекстов, главным образом - с «Путешествием в Арзрум» и «Капитанской дочкой». Все это позволяет интерпретировать «киргизскую сказку» не как маргинальную инкрустацию, но как интратекстуально значимый фрагмент романа. Это, в свою очередь, дает основания думать, что набоковская литературная работа с «бродячими сюжетами» и фольклорными текстами если не находилась под влиянием компаративной школы А.Н. Веселовского, то по крайней мере была довольно близка к приемам и методам последней.

Ключевые слова: Набоков, «Дар», фольклор, ориентализм в русской литературе.

Информация об авторе: Александр Александрович Панченко - доктор филологических наук, профессор РАН, Институт русской литературы (Пушкинский Дом) Российской академии наук, наб. Макарова, д. 4, 199034

г. Санкт-Петербург, Россия. ORCID ID: https://orcid.org/oooo-ooo2-7292-0303

E-mail: apanchenko2008@gmail.com

Для цитирования: Панченко А.А. «Киргизская сказка» в «Даре»: Набоков, фольклор и ориентализм // Studia Litterarum. 202I. T. 6, № I. С. 266-299. https://doi.org/IO.22455/2500-4247-202I-6-I-266-299 


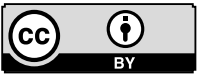

This is an open access article distributed under the Creative Commons Attribution 4.0 International (CC BY 4.0)

Studia Litterarum, vol. 6, no. I, 2O2I

\section{THE "KIRGHIZ FAIRY TALE" IN THE GIFT: NABOKOV, FOLKLORE, AND ORIENTALISM}

(C) 202I. Alexander A. Panchenko Institute of Russian Literature (The Pushkin House) of the Russian Academy of Sciences, St. Petersburg, Russia Received: March 06, 2020 Approved after reviewing: June 22, 2020 Date of publication: March 25, 202I

Abstract: In the second chapter of The Gift, Fyodor Konstantinovich Godunov-Cherdyntsev recalls a "Kirghiz fairy tale" about a human eye that wants "to encompass everything in the world.” The plot of the story goes back to a Talmudic parable about Alexander the Great. The parable was retold in Russian by a number of writers and scholars in the $\mathrm{I}^{\text {th }}$ and early $2 \mathrm{O}^{\text {th }}$ centuries. However, it seems unlikely that Nabokov did use in any original piece of Inner Asian folklore in his novel. More probable is that he invented the "fairy tale" proceeding from one of the Russian versions of the parable. At the same time, Nabokov's version is based on a number of international literary and folkloric motifs and is related to the "Kalmyk fairy tale" in Pushkin's novel The Captain's Daughter and to $\mathrm{I}^{\text {th }}$ century Russian literary fairy tales in verse. While the central theme of Nabokov's parable is the insatiability of human vision and the frailty of life, its con- and subtexts allude to some other recurrent themes of the novel - death and immortality, the quest for paradise, closed doors and exile, sources of love and poetical inspiration. The Oriental coloring of the tale (and the second chapter of the novel in general) appears to be a literary play with a limited number of texts, in particular with The Captain's Daughter and A Journey to Arzrum. This allows discussing the "Kirghiz fairy tale" as an intratextually meaningful part of the novel rather than a marginal encrustation. It seems that Nabokov's literary work with "migratory" plots and folklore texts was in a way close to the methods and ideas developed in Alexander Veselovsky's school of comparative literary studies.

Keywords: Nabokov, The Gift, folklore, orientalism in Russian literature.

Information about the author: Alexander A. Panchenko, DSc in Philology, Professor of the Russian Academy of Sciences, Institute of Russian Literature (The Pushkin House) of the Russian Academy of Sciences, Makarov emb., 4, I99034 St. Petersburg, Russia. ORCID ID: https://orcid.org/oooo-0002-7292-0303

E-mail: apanchenko2008@gmail.com

For citation: Panchenko, A.A. "The "Kirghiz Fairy Tale" in The Gift: Nabokov, Folklore, and Orientalism." Studia Litterarum, vol. 6, no. I, 202I, pp. 266-299. (In Russ.) https://doi.org/IO.22455/2500-4247-202I-6-I-266-299 
Во второй главе романа «Дар», заново переживая последнее прощание с пропавшим без вести отцом, Федор Константинович Годунов-Чердынцев вспоминает следующую историю:

Хотя отец фольклора недолюбливал, он бывало приводил одну замечательную киргизскую сказку. Единственный сын великого хана, заблудившись во время охоты (чем начинаются лучшие сказки и кончаются лучшие жизни), заприметил между деревьями какое-то сверкание. Приблизившись, он увидел, что это собирает хворост девушка в платье из рыбьей чешуи; однако не мог решить, что именно сверкало так, лицо ее или одежда. Пойдя с ней к ее старухе матери, царевич предложил дать в калым кусок золота с конскую голову. «Нет, - сказала невеста, - а вот возьми этот мешочек - он, видишь, едва больше наперстка, да и наполни его». Царевич, рассмеявшись («И одна, - говорит, - не войдет»), бросил туда монету, бросил другую, третью, а там и все бывшие при нем. Весьма озадаченный, пошел он к своему отцу. Все сокровища собрав, все в мешочек побросав, хан опустошил казну, ухо приложил ко дну, накидал еще вдвойне, - только звякает на дне. Призвали старуху: «Это, - говорит, - человеческий глаз, хотящий вместить все на свете», - взяла щепотку земли да и разом мешочек наполнила (курсив мой. А.П.) $[47$, т. 4 , с. 316-3I7].

Помимо неожиданного хореического вкрапления (о котором еще пойдет речь ниже), этот пассаж интересен и в контексте международной истории «бродячих» сюжетов, и в связи с несколькими лейтмотивами самого набоковского романа. Омри Ронен в своей статье «Девять примечаний к 
“Дару” отметил, что сюжет «киргизской сказки» отыскивается в еврейской традиции, а именно в талмудических притчах об Александре Македонском: «Сказка..., которую любил вспоминать отец Годунова-Чердынцева, имеет близкую параллель в талмудической легенде об Александре Великом. Набоков мог прочитать ее в русском издании: “Агада. Сказания, изречения, притчи Талмуда и Мидрашей” (Берлин: Изд. С.Д. Зальцман, І922. С. 232)» [37, с. 23].

Ронен, таким образом, полагает, что Набоков мог прочитать историю об Александре Македонском в «Агаде» Хаима Бялика и Иегуды Равницкого, переведенной на русский язык Семеном Фругом. Первое русское издание этого сборника, кстати, вышло в Одессе в I9Iо-І9I4 гг., так что писатель теоретически мог быть знаком и с ним. Здесь притча звучит следующим образом:

На обратном пути остановился Александр для обеда близ одного ручья. Поданную ему соленую макрель царь начал обмакивать в воду ручья - и рыба получала удивительно приятный запах.

- Это доказывает, - сказал Александр, - что ручей этот течет из рая.

Помыв лицо свое в воде ручья, Александр направился по истокам его и дошел до врат рая.

- Отворите! - воскликнул Александр.

- Врата эти - Господни, праведники входят через них, - услышал он в ответ.

- Но я царь, и я знаменит, - сказал Александр, - дайте же мне какуюнибудь вещь на память.

Дали ему черепную кость. Придя в свое царство, Александр положил на одну чашу весов эту кость, а на другую все серебро и золото, бывшее при нем. Перевешивала кость.

- Что значит это? - спросил Александр у мудрецов.

- Эта кость, - ответили мудрецы, - орбита человеческого глаза, ненасытного в жадности своей.

- Чем вы это докажете?

- Возьми горсть земли и посыпь кость [42, с. I72].

В оригинальной версии Вавилонского Талмуда (Тамид, 32б) та же история изложена немного иначе: 
В пути остановился он у источника с водой, сел и начал есть хлеб. Была у него с собой соленая рыба. Он помыл ее и почувствовал приятный запах. Воскликнул Александр: «Не из райского ли сада вода этого источника?»

Рассказывают также, что он зачерпнул воды из источника и помыл лицо. Некоторые же утверждают, что он черпал воду, пока не пришел ко входу в райский сад. Крикнул царь громким голосом: - Откройте мне ворота! Ответили ему: - «Вот врата Господни, праведники входят в них» (Пс. II8: 20). Тогда Александр сказал: - Я все-таки царь и чего-то стою. Дайте мне хотя бы малость. Дали ему череп. Взвесил Александр подарок, и оказался череп тяжелее всего золота и серебра в царской сокровищнице.

Спросил царь у еврейских мудрецов: - Что это? Ответили ему: - Это череп человека, глаза которого были ненасытны и желаниям его не было предела. - Чем вы это докажете? Взяли мудрецы щепотку пыли, засыпали в глазницы черепа, и тот немедленно взлетел на весах. Ибо написано: «Как Шеол [царство мертвых] и погибель ненасытны, так и глаза человека ненасытны» (Прит. 27: 20). [9, с. 50 ${ }^{\mathrm{I}}$.

Примечание Ронена было впоследствии оспорено и дополнено Дитером Циммером и Сабине Хартманн в исследовании об источниках «центрально-азиатских» реминисценций в «Даре» [4I, с. 67-68]. Они отметили, «что у Набокова отсутствуют специфические талмудические элементы

I B другой публикации этого фрагмента, сделанной теми же авторами, речь идет не о благоуханной, а об оживающей рыбе: «В пути остановился он у источника с водой, сел и начал есть хлеб. Была у него с собой соленая рыба. Он помыл ее, и ожила рыба. Воскликнул Александр: «Не из райского ли сада вода этого источника?» Рассказывают также, что он зачерпнул воды из источника и помыл лицо. Некоторые же утверждают, что он черпал воду, пока не пришел к входу в райский сад. Крикнул царь громким голосом: «Откройте мне ворота!» Ответили ему: «Вот врата Господни, [праведники входят в них]» (Пс. ІІ8/ІІ7: 20). Тогда Александр сказал: «Я все-таки царь и чего-то стою. Дайте мне хотя бы малость». Дали ему череп. Взвесил Александр подарок, и оказался череп тяжелее всего золота и серебра в царской сокровищнице. Спросил царь у еврейских мудрецов: «Что это?» Ответили ему: «Это череп человека, глаза которого были ненасытны, и желаниям его не было предела». - «Чем вы это докажете?» Взяли мудрецы щепотку пыли, засыпали в глазницы черепа, и тот немедленно взлетел на весах. Ибо написано: «Как Шеол [царство мертвых] и погибель ненасытны, так и глаза человека ненасытны» (Притч. 27: 20)» [18, с. 316]. О путанице с этим эпизодом в переводах на русский и другие европейские языки см.: [8, с. І2I-I22]. Так или иначе, и у Псевдо-Каллисфена, и в позднейших текстах об Александре речь, как правило, идет об оживающей рыбе или птице, что вполне логично с точки зрения принципа «минимального контринтуитивного эффекта». 
(райский сад, череп, мудрецы), так что он, очевидно, вообще не использовал еврейскую версию. Европейский прототип романа об Александре - это текст Псевдо-Каллисфена (около 200 г. н.э.); одна из его производных - Iter ad Paradisum - включает ту же историю. Легенды об Александре (Искандере) сохранялись и повсюду на Востоке, включая средневековое Чагатайское ханство (где расположен современный Киргизстан). Так что сказка Набокова вполне может быть именно тем, чем она названа [в романе] - киргизской легендой» [4I, с. 67-68]. Правда, Циммеру и Хартманн не удалось найти соответствующей истории в известных им публикациях тюркского фольклора. Наконец, здесь же немецкие исследователи напоминают, что тот же сюжет присутствует в поэме Низами «Искандер-наме», и заключают: «Хотя тут нужна более четкая дешифровка, [в романе] присутствует едва различимая и скрытая цепочка ассоциаций, соединяющая Александра, Марко Поло, Одорика, “сэра Джона Мандевилля, рыцаря”, Пржевальского и Годунова в их поисках центрально-азиатского рая» [4I, с. 67-68].

В действительности текстологическая история набоковской «киргизской сказки» еще сложнее, чем это представлялось Ронену, Циммеру и Хартманн. Талмудический текст состоит из двух эпизодов - рассказа о чудесном источнике (у Псевдо-Каллисфена и в некоторых других версиях сюжета это - вода бессмертия), текущем от райских врат, и притчи о «ненасытном глазе». В третьей (так называемая «лямбда») редакции «Романа об Александре» Псевдо-Каллисфена (II, 39) есть история об ожившей рыбе (дополненная рассказом о поваре и дочери Александра, утаивших от полководца воду бессмертия), однако притча о глазе отсутствует [7, с. 222, 228-230; 38 , c. 4; 31, с. 24; 30, с. 360-362], что, по всей видимости, говорит о еврейском происхождении последней (вероятно, в связи со специфической ближневосточной традицией поверий о «дурном глазе» и зависти, см.: [40; 32]). В Талмуде она, кроме того, служит своего рода глоссой к конкретному изречению из Притчей Соломоновых (27: 20). В средневековой европейской литературе об Александре Македонском притча о глазе впервые появляется только в анонимном латинском тексте XII в. «Путешествие Александра Великого в рай» (Alexandri Magni Iter ad Paradisum) [7, c. 278-279; 37, с. I9; 3І, с. 24], что опять-таки позволяет некоторым исследователям говорить о еврейском происхождении его автора [39]. Именно при посредстве этой повести притча о ненасытном глазе получает распространение в западноевропейских текстах 
об Александре [15, с. 63-65; 19, с. 39; 33, с. 206-207; 36, с. 332, 350-352, 356]. Здесь она, однако, несколько отличается от талмудической версии. Вот, например, как звучит один из итальянских вариантов сюжета:

...Александр достигает края света у реки Гихон и пытается проникнуть в стоящий там замок. Не сам Александр, а двое из его воинов встречают старца, живущего в чудесном замке. Старец слышит, как воины обсуждают стремление Александра покорить весь мир, и дает им камень размером с орех в форме человеческого глаза. Он просит передать Александру: «Скажите своему повелителю, что так выглядит мир, который он хочет покорить». Александр не понимает, о чем идет речь, и призывает на помощь своего наставника Аристотеля. Аристотель взвешивает камень, и тот весит больше, чем золотые монеты. Только когда Аристотель мажет глаз слюной, смешанной с пылью, он теряет свой вес. Аристотель объясняет: когда Александр умрет, даже самые легкие предметы будут весить больше, чем он. После этого Аристотель бросает камень в реку [36, с. 350-35I].

Параллельно с западноевропейскими получают распространение иудейские и исламские версии притчи о ненасытном глазе. Они присутствуют, что логично, в еврейских версиях «Романа об Александре» [3I, с. 36], хотя претерпевают некоторые изменения по сравнению с талмудическим текстом и Псевдо-Каллисфеном: ожившие рыбы из эпизода с водой жизни заменяются птицами, глаз помещается в ящике, который не под силу поднять человеку, а сам Александр тайно совершает обрезание у райских врат (что, впрочем, не помогает ему пройти внутрь). Вот как звучит эта история в пересказе А.Я. Гаркави:

На десятый день один из царских охотников (или птицеловов) словил птиц, задушил их..., а когда он положил их в речную воду для того, чтобы их омыть, они ожили и улетели. Увидев это, царский слуга поспешно напился из этой реки и затем пошел и рассказал об этом царю. Царь сказал: «Наверно, это вода из рая..., кто ее пьет - будет вечно жить». <...>

И отправился царь со всем своим войском, переправился через реку и прибыл к воротам вышиною в двадцать... локтей. Пока он удивлялся высоте ворот, царь услышал голос, несшийся к нему: «Вот врата Господни, правед- 
ники в них вступают» (Пс. II8/II7: 20...). И царь поднял свои глаза, и увидел начерченные на воротах буквы, и позвал к себе писца Менахема, который прочитал эти буквы, и оказалось, что там написано: «Возвысьте, врата, главы свои, возвысьтесь, двери вечности!» (Пс. 24/23: 7) И царь ушел оттуда и странствовал со всем своим войском целых шесть месяцев между горами. По окончании же шести месяцев кончились горы..., и показалась большая равнина, а на равнине красивые врата, такие высокие, что глазу не одолеть их высоты. На этих вратах также начертаны большие и чрезвычайно красивые буквы. По прочтении Менахемом этих букв оказалось, что там написано: «Вот врата» и т. д. (Пс. ІІ8/ІІ7: 20), и Менахем объяснил царю эти буквы и слова. И сказал царь: «Кто тут находится при этих воротах?» На это голос ответил: «Это врата рая, и никто из необрезанных не может вступить сюда». В ту же ночь Александр совершил обряд обрезания, и... врачи скоро вылечили его превосходными травами, а войска ничего не узнали об этом, так как царь приказал врачам, чтобы они об этом не говорили. На следующий день царь крикнул хранителям... ворот: «Дайте мне дань (или: налог), и я уйду». И они дали ему ящик, в котором находилось нечто подобное глазу. Когда же царь хотел поднять ящик, то не мог и воскликнул: «Что вы такое мне дали?» И они ответили (М. прибавляет: «Это глаз»). И спросил он: «На что он мне?» Они сказали: «Это тебе указание на то, что глаз твой не довольствуется странствованиями по разным землям». И спросил царь: «Что мне делать для того, чтобы я мог поднять ящик?» Ему ответили: «Покрой землею этот глаз, и тогда ты будешь в состоянии сделать с ним, что хочешь; это служит тебе указанием на то, что твой глаз не насытится богатством до тех пор, покуда ты не обратишься в земной прах, из которого ты создан». И царь сделал так, он покрыл землею глаз, поднял его и положил в свою сокровищницу вместе со всеми своими драгоценностями..., для того чтобы он служил ему знамением и воспоминанием о том, что он получил дань (налог) с рая [8, с. II7-I20].

Обработки того же сюжета мы находим не только в «Искандер-наме» Низами (рубеж XII и XIII вв. [49, с. 378-382], но и в написанной несколько позже «Книге о Дарабе» Абу Ахера Тарсуси [55, с. 486-487], а также в «Рассказах о пророках» тюркского писателя XIV в. из Хорезма Рабгузи [3, c. II8]. Встречается он и в позднейших исламских текстах, посвященных пророкам (см., например, соответствующее сочинение современного авар- 
ского шейха: [52, с. 262-264]). Е.А. Костюхин, кроме того, указывает на ряд сказочных текстов об Александре Македонском (грузинский, казахский / киргизский, узбекский), а также на поэму Абая Кунанбаева «Искандер» (конец г890-х гг.?22), где фигурирует притча о ненасытном глазе [19, с. 90-92, I60-I6I]. С историей этих текстов, однако, тоже все не очень просто, и к ним я еще вернусь.

В древнерусских редакциях «Александрии» история о ненасытном глазе, однако, отсутствует ([см.: [20; 27])3. Ронен, по всей видимости, полагал, что первая публикация этой притчи на русском языке - это текст из сборника Бялика и Равницкого. Это, однако, совсем не так. Насколько мне известно, впервые в русской литературе пересказал обсуждаемый талмудический сюжет В.А. Жуковский в «Двух повестях» (г844) (см.: [46, с. г93204, 509-5I4]). Этот пересказ, в свою очередь, представлял собой свободный перевод стихотворения Шамиссо «Сказание об Александре» (I834). И немецкий, и русский поэты прямо указывают на Талмуд как на источник притчи и действительно пересказывают ее довольно близко к оригиналу: правда, благоухающей либо ожившей рыбы у Шамиссо и Жуковского нет, однако чудесный источник, текущий от райских врат, присутствует:

Он подошел к потоку, наклонился,

Рукою зачерпнул воды студеной

И напился; и чудно освежила

Божественно-целительная влага

Его все члены; в грудь его проникла

Удвоенная жизнь. И понял он,

Что из страны, благословенной небом,

Такой поток был должен вытекать,

Что близ его истоков надлежало

2 Точная датировка неизвестна, но предполагается, что свои поэмы Кунанбаев «написал в последний период своего творческого пути» (см.: [27, с. 7]).

3 А.Н. Веселовский [6, с. 46] и И.Н. Жданов [І4, с. 592-596] сопоставляли талмудическую притчу с историями о «неподъемной» суме или камне (Святогор в русских былинах, Сослан нартского эпоса и т. п.; в указателе фольклорно-мифологических мотивов Ю.Е. Березкина и Е.Н. Дувакина (https://ruthenia.ru/folklore/berezkin/) это мотив В83 «Неподъемная тяжесть») в ряду «преданий о зазнавшихся гордецах» [14, с. 592]. Это сравнение представляется мне интересным в типологическом отношении, однако генетические связи соответствующих сюжетов все же вызывают сомнения. 
Цвести земному счастию; что, верно,

Там в благоденствии, в богатстве, в мире

Свободные народы ликовали.

$$
\text { [46, c. I95] }
$$

Следующий по времени пересказ той же притчи на русском языке был предпринят юристом и историком И.Г. Оршанским [23, с. II]. Здесь как раз упоминалась ожившая рыба, а оригинальный талмудический текст был, по признанию самого переводчика, несколько подправлен.

Впрочем, судя по всему, большее значение для популяризации истории о ненасытном глазе в России конца XIX - начала XX вв. сыграла ее публикация под заголовком «Сказание о гордом завоевателе (восточное предание)» в сборнике «Цветник», выходившем в издательстве «Посредник» (о нем см.: [4]) под редакцией последователей Л.Н. Толстого, главным образом - В.Г. и А.К. Чертковых. Идея издания «Цветника» - сборника нравоучительных исторических и литературных текстов для народного чтения - принадлежала известной просветительнице и деятельнице женского движения А.М. Калмыковой. Толстой, однако, не был удовлетворен первоначальным составом рукописи и предложил кружку «Посредника» ее доработать [2]. Первое издание «Цветника» вышло в Киеве в I887 г. с предисловием самого Толстого [56, т. 26, с. 307-309, 57І]. В г888 г. там же был издан новый - переработанный и дополненный вариант сборника. Эта редакция «Цветника» переиздавалась «Посредником» в I889, І892, I897, I903 И І9І2 Гг.

А.К. Черткова вспоминала о работе над сборником следующее:

Сборник «Цветник» был задуман А.М. Калмыковой, но Л<ев> Н<иколаеви>ч большинство рассказов ее подбора забраковал, а другие не одобрил по изложению и сам передал эту рукопись в нашу совместную редакцию для пополнения и переработки. После того рукопись «Цветника» сначала частями, а потом в целом, доставлялась Л<ьву> Н<иколаеви>чу на просмотр. Некоторые рассказы он исправлял сам кое-где, в некоторых местах указывал на необходимость переделки или сокращения в смысле упрощения языка. <...>

Помнится также, что значительные исправления он делал в рассказах «Покаяние», «Старец» и «Прокаженный», также в рассказе «Жаба», о кото- 
ром он упоминает в письме; также оба рассказа об Александре Македонском, в особенности «Сказание о гордом завоевателе» [6I, с. I83-I84].

«Сказание о гордом завоевателе» было включено только во вторую редакцию «Цветника» [58, с. 67-72; 59, с. 67-72]. Здесь, кроме того, напечатан и известный античный анекдот об Александре Македонском и Диогене [58, с. 66-67]. С другой стороны, в «Цветнике» были напечатаны и другие талмудические притчи: «Главный закон» [58, с. 6] («Вся суть Торы» [42, c. 208]), «Бог дал, Бог и взял» [58, с. 94-95] («Отданное на хранение» [42, c. 273-274]), «Самый богатый человек» [58, с. I03-IO4] («Покупка поместья» [42, с. 246-247]), «Еврей Финеас» [58, с. I34-135] («Для чужого урожая» [42, c. 280]). Текст «Сказания» был близок к талмудическому оригиналу, так что он не мог быть пересказом стихотворной повести Жуковского или прозаического пересказа Оршанского; здесь, скорее всего, речь должна идти о переводах из какого-то западноевропейского (или идишского?) сборника притч. При этом, однако, из него были исключены любые упоминания о Талмуде, иудаизме и еврейских мудрецах.

«Сказание» обсуждалось в переписке Толстого и Черткова весной I888 г. Из этих писем можно заключить, что сначала оно должно было войти в начатую Калмыковой, а затем доработанную П.В. Засодимским и Чертковым книгу об Александре Македонском (см.: [45; 43]), но затем по каким-то причинам попало в «Цветник» в качестве отдельной притчи (см.: [56, т. 86, с. I32-I35, I5I-I53]). Судя по всему, «Сказание» было переведено и предложено для изданий «Посредника» именно Чертковым. При этом, как мы видим из письма его жены, правкой текста занимался и сам Толстой.

Дальнейшая судьба этой версии притчи о ненасытном глазе по-своему примечательна. В І895 г. ее дословно перепечатала «Киргизская степная газета» [54], «особое прибавление к Акмолинским областным ведомостям», издававшееся в Омске преимушественно на русском языке и имевшее просветительскую и историко-этнографическую направленность. Именно эту публикацию Костюхин и принял за оригинальную казахскую или киргизскую сказку4. При этом он же обоснованно предположил, что именно ее использовал «основатель казахской литературы» Абай (Ибрагим) Кунанбаев

4 Еще один текст из «Цветника», написанный уже самим Толстым («Отчего зло на свете») и перепечатанный в предыдущем номере газеты, принял за киргизскую сказку 
в своей поэме «Искандер» [19, с. 9г]. Высказывались предположения, что Кунанбаев мог опираться на «Искандер-наме» или на «Две повести» Жуковского [I9, с. 90; 20, с. I3-I4]. Однако в сюжетном отношении «Искандер» Абая ближе всего к тексту «Сказания», так что гипотеза Костюхина представляется наиболее правдоподобной: Кунанбаев мог прочитать толстовскую версию притчи об Александре и в одном из изданий «Цветника», и в «Киргизской степной газете». Казахский фольклорист Сеит Каскабасов, кроме того, отмечает, что встречал эту историю и в живом бытовании: «Сюжет абаевского “Искандера” недавно был зафиксирован нами также в устном бытовании. Правда, сказка состоит из трех сюжетов, второй из которых нас и интересует. Сказочник (тот же А. Тышканбаев), рассказавший нам эту сказку, заявил, что много лет назад он прочитал ее в одной старой религиозной книге, названия которой не помнит» [20, с. I4]. Речь, однако, здесь, по всей видимости, идет именно об исламском варианте сюжета, сильно отличающемся и от талмудического оригинала, и от западноевропейских версий притчи о ненасытном глазе.

Наконец, необходимо вспомнить отмеченные Костюхиным два варианта этого сюжета. Первый - это гурийская сказка, впервые опубликованная по-русски в I939 г. [44, с. 42I-424]. Здесь речь тоже идет об Александре Македонском, однако вместо глазничной кости, черепа или камня фигурирует «маленькое высохшее человечье сердце», а сама притча оказывается составной частью сюжета ATU 98I («Мудрость спрятанного старика спасает королевство»), но не истории о воде жизни и райских вратах. В узбекской сказке «Мудрый лекарь» талмудическая притча подверглась еще большей трансформации: обитатели подводного мира присылают волшебную чашку (которую невозможно наполнить золотом и серебром, если не положить в нее земли), доказывая правителю, что он недостаточно прозорлив и не может ими управлять. Искандеру, кроме того, не удается понять, какими чудесными свойствами обладает насыпанная в чашку мука [57, с. 413-424]. Однако тема ненасытности / бренности человеческого зрения (или чувств и желаний вообще) в этом варианте полностью отсутствует.

Подведем итоги этого краткого текстологического обзора. Притча о человеческом глазе, включенная во вторую главу «Дара» в качестве «кир-

другой фольклорист - В.М. Сидельников, составляя свой «Библиографический указатель по казахскому устному народному творчеству» [53, с. 58]. 
гизской сказки», имеет иудейское происхождение и восходит к талмудическому тексту. Скорее всего, в «Роман об Александре» Псевдо-Каллисфена, а также, возможно, и в некоторые другие восточные и западные тексты об Александре Македонском она попадает непосредственно из Талмуда. В качестве самостоятельного сюжета, имеющего устное распространение, эта история почти не встречается ни в Европе, ни на Ближнем Востоке, ни в Центральной Азии; в результате он не учтен ни в указателе сюжетов Аарне-Томпсона-Утера, ни в указателе мотивов Томпсона (в отличие, например, от сказок о «рогатом Искандере» - ATU 782 («Мидас и ослиные уши»); см.: [19, с. І03-135]. Хотя не исключено, что генезис притчи связан с архаическими представлениями о дурном глазе, ее аллегорическая образность и моралистическое содержание, по-видимому, не способствовали, скажем так, фольклоризации. Русские пересказы этой истории (Жуковского, Оршанского, Черткова / Толстого, Бялика / Равницкого / Фруга) прямо или косвенно восходят к Талмуду. Хотя на Востоке сформировалась собственная традиция повествований об Александре, включающая и этот сюжет (персидская литература, мусульманские предания о пророках), его (псевдо)киргизский и казахский варианты конца XIX в. восходят к публикации в «Цветнике». И романтическая (у Шамиссо и Жуковского), и религиозно-нравоучительная (у Черткова и Толстого) трактовки притчи о ненасытном глазе, однако, по-видимому, не оказали сколько-нибудь заметного влияния на массовую культуру.

Попробуем теперь высказать некоторые предположения касательно появления «киргизской сказки» в романе Набокова. Повторю, что варианты талмудической притчи о ненасытном глазе действительно могли попадать в фольклор Центральной Азии и Ближнего Востока, однако не имели здесь сколько-нибудь широкого распространения. Это, впрочем, вполне естественно, поскольку символизм этого сюжета в целом плохо соответствует топике и волшебной, и новеллистической сказки. Хотя Циммер и Хартманн допускают, что источником Набокова могла быть «киргизская легенда», сами они такого текста не нашли, при том, что их обзор текстов, использованных во второй главе «Дара», представляется очень подробным и хорошо фундированным. Неизвестен такой текст и Костюхину, уделившему существенную часть своей монографии фольклорным (и, в частности, центрально-азиатским) сюжетам об Александре Македонском, в том числе 
и притче о глазничной кости. Мы вправе допустить, таким образом, что Набоков все же не пользовался реально существующим текстом из киргизской (или какой-либо иной азиатской) фольклорной традиции, а сочинил эту «сказку» сам на основании какой-то из версий талмудической притчи. Если исходить из этой гипотезы, необходимо задуматься о непосредственном источнике, которым пользовался писатель, а также о причинах, заставивших его включить именно такую версию сюжета в текст романа.

А.А. Долинин, комментируя включенное в «сказку» шестистишие, отмечает: «Классическая модель сказки в стихах, написанной рифмованным четырехстопным хореем с мужскими клаузулами, - “Спящая царевна” (183I) Жуковского» [13, с. 2I2]. Действительно, стих Набокова в данном случае отличается от других хрестоматийных стихотворных сказок XIX в., написанных хореем: скажем, и у Пушкина, и у Ершова мы встречаем чередование мужских и женских окончаний 5 . Стоит ли видеть здесь сознательную отсылку к Жуковскому? Вполне возможно, что да. Правда, «Две повести» написаны нерифмованным пятистопным ямбом, однако если Набоков действительно их читал, то он мог именно так «зашифровать» соответствующую сюжетную аллюзию. В любом случае отсылка к русским литературным сказкам XIX в. здесь вполне очевидна, и к ней я еще вернусь.

Поскольку в «Даре» речь идет именно о киргизской сказке, у комментатора возникает соблазн как-то связать это с публикацией в «Киргизской степной газете» или с поэмой Кунанбаева. Здесь, однако, все довольно проблематично. Трудно сказать, каким образом в руки Набокову мог попасть экземпляр этого провинциального периодического издания, а «Искандер» Абая, судя по всему, был переведен на русский только в г940 г. Впрочем, писатель, конечно, мог быть знаком и с публикацией в «Цветнике», и со сборником Бялика-Равницкого в переводе Фруга (и, что, наверное, менее вероятно, с упоминанием истории о ненасытном глазе в специальных филологических трудах А.Н. Веселовского, И.Н. Жданова, А.Я. Гаркави, В.М. Истрина, см. выше). Поскольку, как уже было сказано, все пересказы талмудического сюжета на русском языке не отличаются существенной

5 Забавно, что автор недавней докторской диссертации о Набокове (здесь, помимо всего прочего, Ф.К. Годунов-Чердынцев представлен адептом исихазма и буддизма), комментируя этот текст, путает ямб с хореем: «Кульминация сюжета сказки сопровождается переходом из прозы в ямбический стих» [II, c. I54]. Что, как сказал бы Набоков, вновь возвращает нас к Пушкину. 
вариативностью, с текстологической точки зрения проблема непосредственного источника здесь, наверное, не так уж и важна. Более значима она, однако, в связи с вопросами о том, зачем вообе понадобилась Набокову «киргизская сказка» и почему (если мои текстологические предположения верны) он именно так обработал еврейский сюжет об Александре Македонском. Попробуем на них ответить.

Представляется вполне вероятным, что одним из основных претекстов «киргизской сказки» была «калмыцкая сказка», которую Пугачев рассказывает Гриневу в одиннадцатой главе «Капитанской дочки»:

- Слушай, - сказал Пугачев с каким-то диким вдохновением. - Расскажу тебе сказку, которую в ребячестве мне рассказывала старая калмычка. Однажды орел спрашивал у ворона: скажи, ворон-птица, отчего живешь ты на белом свете триста лет, а я всего-навсего только тридцать три года? - Оттого, батюшка, отвечал ему ворон, что ты пьешь живую кровь, а я питаюсь мертвечиной. Орел подумал: давай попробуем и мы питаться тем же. Хорошо. Полетели орел да ворон. Вот завидели палую лошадь; спустились и сели. Ворон стал клевать да похваливать. Орел клюнул раз, клюнул другой, махнул крылом и сказал ворону: нет, брат ворон; чем триста лет питаться падалью, лучше раз напиться живой кровью, а там что Бог даст! - Какова калмыцкая сказка?

- Затейлива, - отвечал я ему. - Но жить убийством и разбоем значит по мне клевать мертвечину.

Пугачев посмотрел на меня с удивлением и ничего не отвечал [5I, т. 6, c. 337-338].

Обе «сказки» сходны в нескольких отношениях. Прежде всего, в жанровом отношении это, собственно говоря, не сказки, а притчи со своего рода ориентальной атрибуцией: и «дикое вдохновение» разбойника, и образ ненасытного человеческого зрения, усмиряемого лишь смертью, приписываются не русскому, а азиатскому кочевническому фольклору. Кроме того, оба нарратива занимают особое и по-своему заметное место в повествовательной структуре и того, и другого романа - как единственные образчики «народной» нравоучительной прозы. Наконец, если Набоков, используя реально существующий бродячий сюжет, подверг его существенной 
переработке, то калмыцкая сказка, по всей видимости, была вообще придумана самим Пушкиным.

Комментаторы «Капитанской дочки» в данном случае обычно ограничиваются кратким замечанием, согласно которому «фольклорный источник» пушкинского текста «пока что не найден». Это действительно так, и международные указатели опять-таки не знают соответствующего сюжета. Ни в русском, ни калмыцком фольклоре он не известен, за исключением нескольких позднейших пересказов, которые, по всей видимости, вторичны по отношению к пушкинскому тексту (источниковедческий обзор по этому поводу см.: [5; 16]). При этом структурно-семиотические [5] и религиозно-философские [I7] интерпретации «калмыцкой сказки», предпринятые названными авторами, представляются мне излишне сложными: противопоставление орла-хищника и ворона-падальщика 6 , которое, конечно, может согреть душу структуралиста, отсылает к довольно очевидным оппозициям благородства и низости, свободы и конформизма, дикости и цивилизации, краткого и долгого жизненного удела. Если уж говорить о каких-то возможных источниках или претекстах, то здесь, вероятно, стоит задуматься о соответствующих басенных сюжетах, о фольклорной балладе или о топике европейского романтизма в целом.

Вряд ли, конечно, Набоков мог квалифицированно определить происхождение «калмыцкой сказки» Пугачева. Важно, однако, что свою «киргизскую» историю он строит сходным образом, существенно перерабатывая при этом оригинальный сюжет притчи. Мы помним, что никакого Александра Великого в «Даре» нет, но взамен появляется «единственный сын великого хана», заблудившийся во время охоты. М.Ю. Лотман высказался по этому поводу следующим образом: «Почему киргизская сказка, начало которой подозрительно напоминает “Пеллеаса и Мелисанду”, заканчивается размером русских сказок Пушкина: четырехстопный хорей парной рифмовки (правда, в отличие от Пушкина, со сплошными женскими окончаниями)?» [2I, с. 223] ${ }^{7}$. Вторая картина соответствующей

6 Подробный обзор символики, связанной с орлом и вороном, в литературе пушкинского времени см. в работе: [26, с. I87-224], при том, что высказанная автором гипотеза касательно конкретного пассажа из «Путешествия в Арзрум» не кажется убедительной (критику см. в: [12]).

7 Спутать мужские и женские окончания, а не ямб с хореем филологу, конечно, простительнее, но и тут исследователю стоило быть внимательнее. 
пьесы Метерлинка действительно похожа на зачин «киргизской сказки», однако это вообще достаточно типичное начало многих сюжетов в фольклоре и средневековой литературе (а в морфологической схеме Проппа соответственно первая функция - «отлучка лица младшего поколения» ез), так что здесь вполне возможен и конкретный источник, скажем, из рыцарского романа или литературной сказки. Собственно говоря, историю о «царском сыне», отставшем от «свиты ловчих», мы встречаем и в «Спящей царевне» Жуковского, так что это опять-таки может быть вполне осознанной аллюзией Набокова. (Соблазнительно, кстати, видеть в герое «киргизского» сюжета самого Федора Константиновича, поскольку тема «охоты» - у отца энтомологической, а у сына литературной - довольно часто появляется на страницах романа; это, однако, плохо доказуемое предположение.) Любопытно при этом, что осколки мотива чудесного источника и опущенной в него рыбы в «Даре» все же остаются: речь идет о девушке «в платье из рыбьей чешуи» (что, вероятно, отсылает к теме набоковских (и пушкинских) русалок, на которой я сейчас останавливаться не буду, см. об этом: [34]). Здесь, кроме того, стоит вспомнить мотив «чудесной» 300-, орнито- или териоморфной супруги, сбрасывающей кожу и превращающейся в прекрасную девушку, который представлен во многих сюжетах группы ATU 400-424. Ни один из известных мне вариантов сюжета о ненасытном глазе не знает темы сватовства, хотя логику писателя понять здесь можно: сватовство в волшебной сказке нередко сопровождается трудными задачами, и именно так у Набокова позиционируется кульминация всей истории: правда, глазную кость, череп или камень, фигурирующие в большинстве вариантов сюжета, приходится заменить «мешочком», что звучит несколько странно: мешочек (если отвлечься от сугубо анатомической стороны дела) плохо сопоставляется с глазом. Кусок золота размером с конскую голову в качестве символа богатства действительно встречается в киргизском фольклоре [50, с. II5-II6, I72]; есть он, впрочем, и в сказках других народов. У Жуковского и в публикации «Цветника» место раввинов, объясняющих Александру смысл происходящего, занимает «мудрец», а в поэме Кунанбаева (как и в некоторых средневековых версиях) - Аристотель. У Набокова это «старуха». При этом моралистические аспекты притчи (у Черткова / Толстого это, главным образом, посрамление гордыни, а в остальных вариантах бренность человеческих 
желаний) в «Даре» несколько размыты, но в целом скорее соответствуют версии Жуковского и Шамиссо:

Мудрец сказал: «Великий государь,

Был некогда подобный твоему

Разрушен череп; в нем же эта кость

Была частицей впадины, в которой

Глаз, твоему подобный, заключался.

Глаз человеческий в объеме мал;

Но с ненасытной жадностью объемлет

Он все, что нас здесь в области видений

Так увлекательно пленяет; целый

Он мир готов сожрать голодным взором.

Все золото земное всыпьте в чашу,

Все скипетры и все короны бросьте

На золото... все будет мало; но

Покрой его щепоткою земли -

И пропадет его ненасытимость;

Сквозь легкий праха груз уж не пробьется

Он жадным взором. Ты ж, великий царь,

В сем знаменье уразумей прямое

Значение и времени и жизни.

Ненасытимости перед тобою

Лежит символ в истлевшей этой кости».

Если я прав и Набоков действительно переработал повесть Жуковского и/или «Сказание о гордом завоевателе», то представляется в равной степени интересным, что он заимствовал из оригинальных источников и что оставил, так сказать, в подтексте. Тема особого художественного зрения (и литературного дара его словесного воплощения) - одна из центральных в романе. Этот предмет многократно обсуждался исследователями, так что у меня нет нужды останавливаться на нем подробнов, Отмечу только, что

8 Ср. также тему «ненасытного зрения» в «Других берегах»: «Моя нежная и веселая мать во всем потакала моему ненасытному зрению. Сколько ярких акварелей она писала при мне, для меня! Какое это было откровение, когда из легкой смеси красного и синего вырастал куст 
зрение в «Даре» представляет собой не просто эстетическую, но и, скажем так, экзистенциальную категорию: глаз оказывается своего рода средоточием души. Рассуждая в пятой главе романа о смерти, Набоков (или один из его героев) вспоминает следующую цитату из выдуманного писателем «французского мыслителя» Делаланда: «Наиболее доступный для наших домоседных чувств образ будущего постижения окрестности долженствующей раскрыться нам по распаде тела, это - освобождение духа из глазниц плоти и превращение наше в одно свободное сплошное око, зараз видящее все стороны света, или, иначе говоря: сверхчувственное прозрение мира при нашем внутреннем участии» [47, т. 4, с. 484]. Очевидно, что этот пассаж прямо корреспондирует с «киргизской сказкой»: человеческий глаз, согласно талмудической притче, смертен и при всей своей ненасытности может быть легко заполнен землею, но душа (или, точнее, художественное зрение) - как «одно свободное сплошное око» - способна существовать и вне «глазниц плоти».

В этом контексте с лейтмотивами романа могут быть связаны и те части и образы нашей истории об Александре Македонском, которые в «киргизской сказке» отсутствуют: волшебный источник (вода вечной жизни), приводящий полководца к закрытым дверям рая, путешествие в чудесную, но и опасную восточную страну (или страну мрака). Дональд Бартон Джонсон в своей статье «Шахматный ключ к роману “Дар”» замечает, что тема ключей у Набокова обыгрывается омонимически: речь идет и о дверных ключах (утраченных или не подходящих к замкам и символизирующих изгнание, но вместе с тем сохраняющуюся связь с русской культурой), и о «ключах-источниках», указывающих одновременно на любовь и вдохновение [Іо, с. I35-I54]. Что-то подобное мы можем увидеть и в притче о ненасытном глазе. Все это, как мне кажется, делает более понятной ту цепочку ассоциаций, - начинающуюся от Александра9 и заканчивающуюся на Константине Кирилловиче Годунове-Чердынцеве, - о которой говорят Циммер и Хартман. Цепочка эта так или иначе основана на ориенталистской топике: речь идет и о привычных для христианских культур поисках земного рая на персидской сирени в райском цвету!» [47, т. 5, с. 158$]$. В той же главе Набоков вспоминает якобы бывший с ним в детстве случай болезненного «ясновидения» (гигантский карандаш, купленный матерью), который фигурирует и в г главе «Дара».

9 С сюжетом и топикой «Романа об Александре» Набоков мог быть знаком по повести Кузмина «Подвиги Великого Александра» (1909). О ней см.: [24]. 
востоке, и об Азии как неведомой части света, источнике географических, энтомологических и прочих открытий и прозрений.

В нашем случае, как и у Пушкина, ориентализм отчасти пересекается с фольклоризмом. Стоит, однако, помнить, что тема фольклорно-этнографической экзотики в «Даре» с самого начала звучит двойственно и по-своему странно. Уже в первой главе мы узнаем, что отец героя «не терпел этнографии», однако «случайно привозил из своих баснословных путешествий» разные экзотические диковины, среди них - «шаманский бубен, к нему заячья лапка, сапог из кожи маральих ног со стелькой из коры лазурной жимолости, тибетская мечевидная денежка, чашечка из кэрийского нефрита, серебряная брошка с бирюзой, лампада ламы, - и еще много тому подобного хлама» [47, т. 4, с. 202]. Здесь же Федор Константинович вспоминает вошедшую в его детские кошмары сцену жертвоприношения лошади алтайскими камами, о которой он, по всей вероятности, слышал от отца, а Набоков знал по этнографическим очеркам миссионера Василия Верещагина [I3, с. 75]. Во второй главе о неприязни Годунова-Чердынцева к антропологической экзотике сообщается не только в пассаже о киргизской сказке, но и более развернуто:

Этнография не интересовала его вовсе, что некоторых географов весьма почему-то раздражало, а большой приятель его, ориенталист Кривцов, чуть ли не плача укорял его: «Хоть бы ты одну свадебную песенку привез, Константин Кириллович, хоть бы одежку какую изобразил». Был один казанский профессор, который особенно нападал на него, исходя из каких-то гуманитарно-либеральных предпосылок, обличая его в научном аристократизме, в надменном презрении к Человеку, в невнимании к интересам читателя, в опасном чудачестве, - и еще во многом другом. А как-то, на международном банкете в Лондоне (и этот эпизод мне нравится всего больше), Свен Гедин, сидевший с моим отцом рядом, спросил его, как это так случилось, что, неслыханно свободно путешествуя по запретным местам Тибета, в непосредственной близости Лхассы, он не осмотрел ее, на что отец отвечал, что ему не хотелось пожертвовать ни одним часом охоты ради посещения еще одного вонючего городка (one more filthy little town), - и я так ясно вижу, как он должно быть прищурился при этом [47, т. 4, с. 297]. 
Получается, таким образом, что фольклорно-этнографический ориентализм - в качестве эстетики или идеологии - вроде бы чужд отцу и сыну Годуновым-Чердынцевым ${ }^{\text {Iо }}$. Вместе с тем он все же присутствует в их жизни и воображении. Более того, представления о фольклоре вообще и специально о сказке в романе - по крайней мере, отчасти - связываются с образом Востока. Правда, связь эта появляется в довольно специфическом контексте, а именно в книге о Чернышевском, написанной Федором Константиновичем. В Саратове шестнадцатилетний Чернышевский изучает персидский язык. «В 75 году (Пыпину) и снова в 88 г. (Лаврову) он посылает “староперсидскую поэму”: страшная вещь! В одной из строф местоимение “их” повторяется семь раз (“от скудости стран их, тела их скелеты, и сквозь их лохмотья их ребра видать, широки их лица, и плоски черты их, на плоских чертах их бездушья печать”), а в чудовищных цепях родительных падежей (“От вопля томленья их жажды до крови...”) на прощание, при очень низком солнце, сказывается знакомое тяготение автора к связности, к звеньям» [47, т. 4, с. 465-466]. В І883 г. в Иркутске, возвращаясь из ссылки, Чернышевский рассказывает детям жандармского начальника Келлера «“более или менее персидские сказки - об ослах, розах, разбойниках...” как запомнилось одному из слушателей» [47, т. 4, с. 468]. В действительности речь шла о сказках из «Тысячи и одной ночи» [I3, с. 483], которыми Чернышевский увлекался еще с юности. Стоит добавить, что тема восточных сказок действительно была важна для Чернышевского в разные перио-

Iо Отношение самого Набокова к романтическому фольклоризму и не лишенному ориенталистских и колониальных коннотаций увлечению «местным колоритом» (над которым посмеялся Мериме в «Гюзле» и соответственно Пушкин в «Песнях западных славян») ясно выражено в его позднейшей работе о Гоголе (1944): «Немало скороспелых похвал порождено было местным колоритом, а местный колорит быстро выцветает. Я никогда не разделял мнения тех, кому нравятся книги только за то, что они написаны на диалекте, или за то, что действие в них происходит в экзотических странах. Клоун в одежде, расшитой блестками, мне не так смешон, как тот, что выходит в полосатых брюках гробовщика и манишке. На мой вкус, нет ничего скучнее и тошнотворней романтического фольклора или потешных баек про лесорубов, йоркширцев, французских крестьян или украинских парубков. <...> В период создания “Диканьки” и “Тараса Бульбы” Гоголь стоял на краю опаснейшей пропасти (и как он был прав, когда в зрелые годы отмахивался от этих искусственных творений своей юности). Он чуть было не стал автором украинских фольклорных повестей и красочных романтических историй. <..> Когда я хочу, чтобы мне приснился настоящий кошмар, я представляю себе Гоголя, строчащего на малороссийском том за томом “Диканьки” и “Миргороды” - о призраках, которые бродят по берегу Днепра, водевильных евреях и лихих казаках» (перевод Е. Голышевой) [48, т. I, с. 426-427]. 
ды его жизни, в том числе и в сибирской ссылке. В середине г870-х он пишет жене: «И кроме того, что ученый, я умею быть недурным рассказчиком; от нечего делать я сложил в своих мыслях едва ли меньшее число сказок, чем сколько их в “Тысяче и одной ночи”; есть всяких времен и всяких народов; сказки - это нимало не похоже на публицистику» [6о, т. I4, с. 584]; «После, за Байкалом, я... исписывал очень много бумаги, почти каждый день без пропуска. И со мною жили товарищи, читавшие мои сказки (то были почти все только сказки; некоторые были хорошие; но - время шло, содержание их ветшало, и я бросал в печь одну за другою)» [6о, т. I4, с. 66о].

Правда, когда в І877 г. Пыпин предложил ему записывать и издать якутские сказки, Чернышевский отвечал, что якутского языка не знает, никаких сказок в Вилюйске не слыхал даже по-русски [6о, т. I5, с. 87], да и вообще не любит «этнологию»: «Я понимал, что собирать якутские сказки не мое дело, по-твоему. Я понимал, это было желание “этнологов”. Терпеть их не могу, - всех ученых по “новым наукам”. Все это старая дребедень. Факты собираются; это хорошо. История и этнография становится полнее. Но новых идей тут нет: все было известно - хоть бы Вольтеру. Только он был не педант. А они пересоздают науку! - Когда дойдет до этого в моих ученых письмах к детям, буду много смеяться над этими “биологами” и “этнологами” и “антропологами” » [6о, т. I5, с. I50].

Кроме того, книга, которую Федор Константинович пишет об отце и его азиатских экспедициях, тоже не лишена этнографических деталей. Так, у британского натуралиста Пратта Набоков заимствует истории о «пожилом китайце», поливающем во время пожара, - «горел лес, заготовленный для постройки католической миссии», - «отблеск пламени на стенах своего жилища; убедившись в невозможности доказать ему, что дом его не горит, мы предоставили его этому бесплодному занятию» и о «бритоголовых ламах», распространявших слух, что путешественник ловит детей, «дабы из глаз их варить зелье для утробы своего кодака» [4I, с. 57-58]. Вторая из них (а о подобных слухах рассказывает и Пржевальский), кстати сказать, представляет собой одно из первых свидетельств бытования легенды о похищении человеческих органов в этой части света. В г970-I990-е гг. подобные истории записывал в Монголии польский фольклорист Чубала. В это время здесь, впрочем, утверждали, что кровь или внутренние органы похищенных детей нужны «богатым и пожилым китайцам» для омоложения (см.: [25]). 
Как бы то ни было, эти и подобные этнографические мелочи не складываются у Набокова в более или менее связный нарратив или устойчивую цепочку ассоциаций. При этом, скажем, собственно фольклорные тексты, которыми гнушался отец героя и которые записывали и публиковали авторы (скажем, тот же священник Василий Верещагин или Г.Н. Потанин), использовавшиеся Набоковым для изображения экспедиций по Центральной Азии, в романе никак и нигде не фигурируют. В этом контексте, как мне кажется, стоит задуматься о природе набоковского ориентализма, а также о соотношении последнего с «восточными текстами» русской литературы XIX - начала XX вв.

О российском ориентализме той эпохи написано уже довольно много, однако за существующими работами пока что вряд ли можно различить сколько-нибудь последовательную концепцию. Одна из возможных причин - это сложность и противоречивость этой темы самой по себе. О специфике ориентализма Российской империи по сравнению с описанными Э. Саидом колониальными дискурсами Великобритании и Франции говорили многие исследователи. Здесь и зыбкость границ между метрополией и колониями, и сложности отношения к Европе и Западу в разные периоды русской истории, и различные формы внутренней колонизации (которую я, правда, не склонен понимать так прямолинейно, как это делает А.М. Эткинд [29]). Очевидно, что даже применительно к XIX в. мы можем выделить целую серию различающихся (и содержательно, и хронологически) ориенталистских дискурсов в русской общественной мысли и литературе, в частности - «кавказский», «кочевнический», «индигенный» (т. е. связанный с аборигенными народами Сибири) и т. п. Их преемственность, взаимодействие, связь с колониальной политикой и имперским воображением еще заслуживают, как мне представляется, более специальных и детальных исследований. В нашем случае важно, однако, что ассоциации между фольклором и воображаемым Востоком в русской (и европейской) литературе не ограничиваются эпохой романтизма. Не менее важную роль здесь сыграли идеи Теодора Бенфея, развивавшиеся в России В.В. Стасовым, а затем Г.Н. Потаниным. С другой стороны, интерес культуры русского модернизма к Востоку, выразившийся в том числе в идеологии «скифов», а несколько позднее - евразийства, тоже обладал своего рода фольклорно-этнографической окраской. 
Трудно сказать, правда, насколько хорошо Набоков разбирался в тонкостях филологической компаративистики второй половины XIX начала XX вв. и насколько серьезно он относился к ориенталистским текстам Бальмонта, Брюсова, Белого или Блока. В «Даре» главным претекстом центрально-азиатского травелога открыто называется «Путешествие в Арзрум», и в этом пушкинском тексте мы, конечно, видим совсем другую картину. Исследователи не единожды писали, что Пушкин здесь пытается взглянуть на Восток с европейских или даже ультраевропейских позиций и что, помимо всего прочего, его ориенталистский текст оборачивается историей разочарований:

Главное, что манило его, было - «вырваться из пределов необъятной России». Но турецкий берег Арпачая оказывается уже завоеванным, когда он прибыл туда: «я все еще находился в России». Арзрум приносит ему новое разочарование. В «экзотике» не находил он ничего привлекательного: «Не знаю выражения, которое было бы бессмысленнее слов: азиатская роскошь... Ныне можно сказать: азиатская бедность, азиатское свинство и проч.» Бестужев-Марлинский увидел в Арзруме «стройные минареты мечетей», которые, «сверкая золочеными маковками, казались огромными свечами, теплеющимися перед лицом Аллы» («Красное покрывало»). Пушкин замечает только «мечети низки и темны» [12, с. I62].

Азиатский мир «вонючих городков» у Набокова в этом смысле недалеко ушел от пушкинских «бедности» и «свинства» с той лишь разницей, что в путешествиях Годунова-Чердынцева от Востока остается почти исключительно география вкупе с флорой и фауной, а люди и артефакты помещаются в этих декорациях довольно скупо. Однако, как мы видим, Набоков почему-то не чуждается и несколько неожиданных в этом контексте фольклорно-этнографических вставок, перекликающихся с важными или даже центральными темами романа. На мой взгляд, здесь все же стоит видеть именно литературную игру, так или иначе восходящую к Пушкину и, вероятно, Жуковскому. Не берусь судить, читал ли Набоков во время работы над второй главой романа известную статью М.К. Азадовского о западных источниках сказок Пушкина (1936!) [І], при том, что аллюзию на западноевропейскую сказочную традицию несложно увидеть в «обще- 
ственной уборной», стоящей в берлинском сквере и «похожей на пряничный домик Бабы-Яги» ${ }^{\text {II }}$ Дело в том, что в немногочисленных восточнославянских вариантах сюжета ATU327A («Гензель и Гретель»), о котором здесь, очевидно, идет речь, нет никакого пряничного домика, зато он есть в соответствующем тексте из сборника братьев Гримм. Наблюдения такого рода позволяют вновь задуматься о том, насколько Набоков был знаком со специальными работами по филологической компаративистике, прежде всего Веселовского и Жданова.

Подведем итоги. По всей видимости, «киргизская сказка» из второй главы романа «Дар», основанная на сюжете талмудической притчи об Александре Македонском, непосредственно восходит к одной или нескольким русским версиям этого сюжета XIX - начала XX вв.: стихотворной повести Жуковского, прозаическому пересказу, напечатанному Чертковым в «Цветнике» (и, может быть, его републикации в «Киргизской степной газете»), специальным исследованиям Веселовского, Жданова и Истрина, переводам Оршанского или Фруга. Вместе с тем текст Набокова включает в себя ряд международных сказочных, а также литературных мотивов и, вероятно, написан с оглядкой на «калмыцкую сказку» из «Капитанской дочки», а также на русскую стихотворную сказку первой половины XIX в. Хотя центральной темой набоковской притчи остается ненасытность зрения и бренность человеческой жизни, ее кон- и подтексты указывают на ряд других значимых тем романа: смерти и бессмертия, поисков земного рая, закрытых дверей и изгнания, источников любви и поэтического вдохновения. При этом ориенталистский колорит сказки (и соответствующей главы романа в целом) представляет собой литературную игру с ограниченным кругом претекстов, главным образом - с «Путешествием в Арзрум» и «Капитанской дочкой». Все это позволяет интерпретировать «киргизскую сказку» не как маргинальную инкрустацию, но как интратекстуально значимый фрагмент романа. Это, в свою очередь, дает основания думать, что набоковская литературная работа с «бродячими сюжетами» и фольклорными текстами если не находилась под влиянием компаративной школы Веселовского, то по крайней мере была довольно близка к приемам и методам этой последней.

II B другом месте первой главы показывается и сама обитательница домика: «Из своей пряничной, с леденцовыми оконцами, хибарки вышла старушка с метлой, в чистом переднике, с маленьким острым лицом и непомерно огромными ступнями» [47, т. 4, с. 249]. 
Ю. Левинг в своей книги «Ключи к «Дару»» вслед за М.Э. Маликовой утверждает, что в «глубинах» романа скрыта пародия на сюжеты русской сказки, что Федор Константинович - «типичный волшебный герой, предпринимающий путешествие», что «на своем пути он встречает различных дарителей, главный из которых - его умерший отец» и что, например, хозяйка пансиона «фрау Стобой играет роль Бабы-Яги» [35, с. 2І8-219]. Все это, разумеется, сопровождается отсылками к «Морфологии сказки» Проппа, которую Набоков, конечно, читать мог, но чье влияние, как мне представляется, никак не заметно ни в этом, ни в других сочинениях писателя. И эти соображения, и, например, идеи, высказанные в статье Эдит Хейбер [28] о сказочных мотивах в «Подвиге», не кажутся мне достаточно обоснованными (я уже не говорю об упомянутой работе О.А. Дмитриенко [II], где в русскую прозу Набокова вчитывается вообще все, что угодно, от «Ригведы» и «древнего мифа о небесных женах» до восточнославянских заговорных текстов). Все это, однако, не значит, что Набоков (и в своей ранней, и в поздней прозе) вообще не проявляет интереса к фольклору. Интерес этот, однако, довольно жестко регулируется конкретными правилами литературной игры, и правила эти, как мне, надеюсь, удалось показать, зачастую поддаются расшифровке и экспликации. 


\section{Список литературы \\ Исследования}

I Азадовский М.К. Источники сказок Пушкина // Пушкин: Временник Пушкинской комиссии. М.; Л.: Изд-во АН СССР, І936. Вып. г. С. І34-г63.

Бем А.Л. О «Цветнике» // Толстой. Памятники творчества и жизни. Сб. 2 / ред.

В.И. Срезневского. М.: Задруга, І920. С. І80-І83.

Бертельс Е.Э. Роман об Александре и его главные версии на Востоке.

М.; Л.: Изд-во АН СССР, І948. г88 с.

Блюм А.В. Издательство «Посредник» и его читатели // История русского читателя. Л.: [б.и.], г979. Вып. 3. С. 62-76.

5 Борисова В.В. «Калмыцкая сказка» в романе А.С. Пушкина «Капитанская дочка» // Фольклор народов РСФСР. Межвузовский научный сборник. Уфа: Изд-во Башкирского гос. ун-та, І988. Вып. І5. С. Іо8-гі8.

6 Веселовский А.Н. «Слово о двенадцати снах Шахаиши». По рукописи XV века // СОРЯС АН. СПб.: [б.и.], І88о. Т. ХХ, № 2. С. І-47.

Веселовский А.Н. Из истории романа и повести. Материалы и исследования. СПб.: Тип. Имп. Академии наук, г886. Вып. І: Греко-византийский период. 594 с. Гаркави А.Я. Новые данные для истории романа об Александре. II // Веселовский А.Н. Новые данные для истории романа об Александре. СПб.: Тип. Имп. Академии наук, І892. С. 57-165.

9 Гершович У., Ковельман А. Александр Македонский и еврейские мудрецы // Восточная коллекция: Журнал для всех, кому интересен Восток. 2004 (лето). № 2 (I7). C. 42-5I.

Джонсон Д.Б. Миры и антимиры Владимира Набокова / пер. Т. Стрелковой. СПб.: Симпозиум, 20II. 347 с. Дмитриенко О.А. Сквозь витражное окно: Поэтика русскоязычной прозы Набокова. СПб.: Росток, 20I4. 335 с.

Долинин А.А. Вран - символ казни (Из комментариев к «Путешествию в Арзрум во время похода I829 года») // CON AMORE. Историко-филологический сборник в честь Любови Николаевны Киселевой. М.: ОГИ, 201о. С. I57-I69. Долинин А.А. Комментарий к роману Владимира Набокова «Дар». М.: Новое изд-во, 20І9. 648 с.

I4 Жданов И.Н. Сочинения. СПб.: Тип. Имп. Академии наук, г904. Т. г. 870 с.

I5 Истрин B.M. Александрия русских хронографов. Исследование и текст. М.: Университетская тип., I893. 739 с.

I6 Кичикова Б.А. «Калмыцкая сказка» в романе А.С. Пушкина «Капитанская дочка» - к вопросу об источниках // Монголоведение. Элиста: КалмНЦ РАН, 2016. Вып. 8. С. IO4-ІІз.

I7 Кичикова Б.А. «Калмыцкая сказка» Пугачева - философская притча Пушкина // Вестник КИГИ РАН. 20I6. Т. 28. № 6. С. 77-88. 
Ковельман А.Б., Гершович У. Сокрытое и явленное в Талмуде: Очерк нефилософского мышления на исходе античности. М.: Индрик, 2016. 448 с. Костюхин Е.А. Александр Македонский в литературной и фольклорной традиции. М.: Наука, 1972. І9о с. Қасқабасов С. Таңдамалы. Астана: Фолиант, 20I4. Т. 3: Фольклорная проза казахов. Избранные исследования. 424 с. Лотман М.Ю. А та звезда над Пулковом... Заметки о поэзии и стихосложении В. Набокова // В.В. Набоков: pro et contra. СПб.: РХГИ, 200I. Т. 2 / сост. Б.В. Аверин. С. 213-226.

Лурье Я.С. Средневековый роман об Александре Македонском в русской литературе XV в. // Александрия. Роман об Александре Македонском по русской рукописи XV в. / изд. подгот. М.Н. Ботвинник, Я.С. Лурье и О.В. Творогов. М.; Л.: Наука, І966. С. І45-168. Оршанский Ил. Талмудические сказания об Александре Македонском // Сборник статей по еврейской истории и литературе, издаваемый Обществом для распространения просвещения между евреями в России. СПб.: [б.и.], І866. Кн. І. Вып. І. C. I-I6 (5 пагинации).

24 Панова Л.Г. Игры с Брюсовым: Александр Великий в творчестве Кузмина // Новое литературное обозрение. 2006. № 2 (78). С. 222-240. Этнографическое обозрение. 2014. № 6. С. 22-42.

герменевтики. М.: Языки славянских культур, 2005. $3 \mathrm{I} 4$ с.

27 Султанбеков М. Поэмы Абая: автореф. дис. ... канд. филол. наук. Алма-Ата, г97о. I6 c.

28 Хейбер Э. «Подвиг» Набокова и волшебная сказка // В.В. Набоков: pro et contra. СПб.: РХГИ, 200І. Т. 2 / сост. Б.В. Аверин. С. 7І6-729.

29 Эткинд А.М. Внутренняя колонизация. Имперский опыт России / Авториз. пер. с англ. В. Макарова. М.: Новое литературное обозрение, 2013. 448 с.

30 Amitay O. Alexander in Bavli Tamid: In Search for a Meaning // The Alexander Romance in Persia and the East / Ed. by Richard Stoneman et al. Groningen: Barkhuis Publishing, 2012. P. 349-368.

3I Dönitz S. Alexander the Great in Medieval Hebrew Traditions // A Companion to Alexander Literature in the Middle Ages / edited by Z. David Zuwiyya. Leiden: Brill, 2OII. P. 2I-4O.

32 Elliott J.H. Beware the Evil Eye: the Evil Eye in the Bible and the Ancient World. Volume 3: The Bible and Related Sources. Eugene, OR: Pickwick Publications, 2016.

33 Harf-Lancner L. Medieval French Alexander Romances // A Companion to Alexander Literature in the Middle Ages / edited by Z. David Zuwiyya. Leiden: Brill, 20 II. P. 2OI-230. 
34 Johnson D.B. "L'Inconnue de la Seine" and Nabokov's Naiads // Comparative Literature. I992. Vol. 44. No 3. P. 225-248.

35 Leving Yu. Keys to The Gift: A Guide to Nabokov's Novel. Boston: Academic Studies Press, 20II. 534 p.

36 Morosini R. The Alexander Romance in Italy // A Companion to Alexander Literature in the Middle Ages / edited by Z. David Zuwiyya. Leiden: Brill, 20II. P. 329-364.

37 Ronen O. Nine Notes to "The Gift" // The Nabokovian. 44. Spring 2000. P. 20-26.

38 Stoneman R. Primary Sources from the Classical and Early Medieval Periods // A Companion to Alexander Literature in the Middle Ages / edited by Z. David Zuwiyya. Leiden: Brill, 20II. P. I-20.

39 van Bekkum W.J. Alexander the Great in Medieval Hebrew Literature // Journal of the Warburg and Courtauld Institutes 49 (1986). P. 218-226.

40 Wazana N. A Case of the Evil Eye: Qohelet 4: 4-8 // Journal of Biblical Literature. I26/4. 2007. P. 685-702.

4I Zimmer D.E., Hartmann S. The Amazing Music of Truth: Nabokov's Sources for Godunov's Central Asian Travels in The Gift // Nabokov Studies. Vol. 7. 2002/2003. P. 33-74.

\section{Источники}

42 Агада. Сказания, изречения, притчи Талмуда и Мидрашей / пер. С.Г. Фруга. М.: Раритет, г993. 319 с.

43 Александр Македонский - знаменитый завоеватель, прозванный Великим. М.: Тип. И.Д. Сытина, І890. І37 с.

44 Грузинские сказки / редакция М. Чиковани; пер. Н. Долидзе. Тбилиси: Изд-во и тип. «Заря Востока», І939. 464 с.

45 Два победителя. Царь македонский Александр и римский император Марк Аврелий. СПб.: Типо-лит. Месника и Римана, г890. 228 с.

46 Жуковский В.А. Полн. собр. соч. и писем: в 20 т. М.: Языки славянских культур, 20II. T. 4: Стихотворные повести и сказки / сост. и ред. А.С. Янушкевич. 640 с.

47 Набоков В.В. Собр. соч. русского периода: в 5 т. СПб.: Симпозиум, 2004-2008.

48 Набоков В.В. Собр. соч. американского периода: в 5 т. СПб.: Симпозиум, 2004.

49 Низами Гянджеви. Искендер-намэ. Часть І. Шараф-намэ / пер. и ред. Е.Э. Бертельса, Баку: АзФАН, І940. 477 с.

50 Потанин Г.Н. Казак-киргизские и алтайские предания, легенды и сказки. Пг.: Тип. В.Д. Смирнова, г917. І5г с.

5I Пушкин А.С. Полн. собр. соч.: в го т. / текст проверен и примеч. сост. Б.В. Томашевским. Л.: Наука, І977-1979.

52 Саид-афанди аль-чиркави. История пророков. Махачкала: Нуруль иршад, 2010. T. I. 36I c. 
53 Сидельников В.М. Библиографический указатель по казахскому устному народному творчеству. Алма-Ата: Изд. АН Казахской ССР, г95г. Вып І. Іо2 с.

54 Сказание о гордом завоевателе (Восточное предание) // Киргизская степная газета. І895. № 3. С. 3 .

55 Тарсуси, Абу Ахер. Дараб-наме, или Книга о Дарабе / изд. подгот. Н.Б. Кондырева. М.: Ладомир, 200о. 532 с.

56 Толстой Л.Н. Полн. собр. соч.: в 90 т. М.; Л.: Худож. лит., г935-І964.

57 Узбекские народные сказки: в 2 т. / сост. М.И. Афзалов и др. Ташкент: Изд. лит. и искусства им. Гафура Гуляма, І972. Т. 2. 584 с.

58 Цветник. Сборник рассказов. Новое исправленное и пополненное издание. Киев: Тип. Г.Т. Корчак-Новицкого, І888. І6о с.

59 Цветник. Сборник рассказов. Изд. второе. М.: Тип. И.Д. Сытина, І889. I60 с.

60 Чернышевский Н.Г. Полн. собр. соч.: в І5 т. М.: Гос. изд-во худож. лит., 1939-1953.

6I Письмо А.К. Чертковой о «Цветнике» // Толстой. Памятники творчества и жизни. М.: Задруга, І920. Сб. 2 / ред. В.И. Срезневского. С. І83-І85. 


\section{References}

I Azadovskii, M.K. "Istochniki skazok Pushkina” ["Sources for Pushkin's Fairy Tales”]. Pushkin: Vremennik Pushkinskoi komissii [Proceedings of the Pushkin Commission], vol. I. Moscow, Leningrad, Izdatel'stvo AN SSSR Publ., I936, pp. I34-I63. (In Russ.) Bem, A.L. "O 'Cvetnike'." ["About the Tsvetnik"]. Tolstoi. Pamiatniki tvorchestva i zhizni [Tolstoy. Heritage of Works and Life], vol. 2, ed. V.I. Sreznevskogo. Moscow, Zadruga Publ., I920, pp. I80-I83. (In Russ.)

Bertel's, E.Je. Roman ob Aleksandre i ego glavnye versii na Vostoke [The Alexander Romance and its Main Versions in the East]. Moscow, Leningrad, Izdatel'stvo AN SSSR Publ., I948. I88 p. (In Russ.)

4 Blium, A.V. “Izdatel'stvo 'Posrednik' i ego chitateli” ["Posrednik Publishing House and its Readers"]. Istoriia russkogo chitatelia [The History of Russian Readers], vol. 3. Leningrad, 1979, pp. 62-76. (In Russ.) Borisova, V.V. “'Kalmyckaia skazka' v romane A.S. Pushkina 'Kapitanskaia dochka'.” ["The Kalmyk Fairy Tale in A.S. Pushkin's Novel The Captain's Daughter"]. Fol'klor narodov RSFSR [Folklore of the Russian Federation], issue I5. Ufa, Izdatel'stvo Bashkirskogo gosudarstvennogo universiteta Publ., I988, pp. Io8-II8. (In Russ.) Veselovskii, A.N. “'Slovo o dvenadcati snah Shahaishi.' Po rukopisi XV veka” [“The Tale of Shahaishi's Twelve Dreams. From a I $5^{\text {th }}$ Century Manuscript”]. Sbornik otdeleniia russkogo iazyka i slovesnosti Imperatorskoi akademii nauk, vol. XX, no. 2, I88o, pp. I-47. (In Russ.)

7 Veselovskii, A.N. Iz istorii romana i povesti. Materialy i issledovaniia [From the History of Novels and Stories. Materials and Research], issue I: Greko-vizantiiskii period [The Greek-Byzantine Period]. St. Petersburg, Tipografiia Imperatorskoi akademii nauk Publ., I886. 594 p. (In Russ.)

8 Garkavi, A.Ia. "Novye dannye dlia istorii romana ob Aleksandre. II" ["New Data about the Alexander Romance. II"]. Veselovskii, A.N. Novye dannye dlia istorii romana ob Aleksandre [New Data about the History of the Alexander Romance]. St. Petersburg, Tipografiia Imperatorskoi akademii nauk Publ., I892, pp. 57-I65. (In Russ.)

9 Gershovich, U., and Kovel'man, A. "Aleksandr Makedonskii i evreiskie mudrecy” [“Alexander of Macedon and Jewish Sages”]. Vostochnaia kollekciia: Zhurnal dlia vseh, komu interesen Vostok, no. 2 (I7), Summer 2004, pp. 42-5I. (In Russ.) Johnson, D.B. Miry i antimiry Vladimira Nabokova [Worlds in Regression. Some Novels of Vladimir Nabokov], trans. from English by T. Strelkova. St. Petersburg, Simpozium Publ., 20II. 347 p. (In Russ.)

II Dmitrienko, O.A. Skvoz' vitrazhnoe okno: Poetika russkoiazychnoi prozy Nabokova [Through a Stained-Glass Window: the Poetics of Nabokov's Russian Prose].

St. Petersburg, Rostok Publ., 20I4. 335 p. (In Russ.) Dolinin, A.A. "Vran - simvol kazni (Iz kommentariev k 'Puteshestviiu v Arzrum vo vremia pohoda I829 goda')" ["Raven, a Symbol of Punishment (From Comments on 
A Journey to Arzrum during the Campaign of I829)"]. CON AMORE. Istorikofilologicheskii sbornik v chest' Liubovi Nikolaevny Kiselevoi [CON AMORE. Historical and Philological Papers in Honor of Liubov' Nikolaevna Kiseleva]. Moscow, OGI Publ., 20IO, pp. I57-I69. (In Russ.)

I3 Dolinin, A.A. Kommentarii k romanu Vladimira Nabokova "Dar" [Comments on Nabokov's Novel The Gift]. Moscow, Novoe izdatel'stvo Publ., 20I9. 648 p. (In Russ.)

I4 Zhdanov, I.N. Sochineniia [Collected Papers], vol. I. St. Petersburg, Tipografiia Imperatorskoi Akademii nauk Publ., I904. 870 p. (In Russ.)

I5 Istrin, V.M. Aleksandriia russkih hronografov. Issledovanie i tekst. [The Alexander Romance in Russian Chronicles]. Moscow, Universitetskaia tipografiia Publ., I893. 739 p. (In Russ.)

Kichikova, B.A. “'Kalmyckaia skazka' v romane A.S. Pushkina 'Kapitanskaia dochka' k voprosu ob istochnikah” ["The 'Kalmyk Fairy Tale' in A.S. Pushkin's Novel The Captain's Daughter: Sources Revisited”]. Mongolovedenie [Mongol Studies], vol. 8. Jelista, KalmNC RAN Publ., 20I6, pp. IO4-II3. (In Russ.)

Kichikova, B.A. “'Kalmyckaia skazka' Pugacheva - filosofskaia pritcha Pushkina” ["The 'Kalmyk Tale' Narrated by Pugachev - Pushkin's Philosophic Parable”]. Vestnik KIGI RAN, vol. 28, no. 6, 20I6, pp. 77-88. (In Russ.)

I8 Kovel'man, A.B., and Gershovich, U. Sokrytoe i iavlennoe v Talmude: Ocherk nefilosofskogo myshleniia na ishode antichnosti [Hidden and Explicit in the Talmud: A Study of Non-Philosophic Thinking in the Late Antiquity]. Moscow, Indrik Publ., 2016. 448 p. (In Russ.)

I9 Kostiuhin, E.A. Aleksandr Makedonskii v literaturnoi ifol'klornoi tradicii [Alexander of Macedon in Literary and Folkloric Tradition]. Moscow, Nauka Publ., I972. I90 p. (In Russ.) proza kazahov [Kazakh Prose Foklore]. Astana, Foliant Publ., 20I4. 424 p. (In Russ.) Lotman, M.Iu. "A ta zvezda nad Pulkovom... Zametki o poezii i stihoslozhenii V. Nabokova” [“And yon Star Sheds on Pulkovo Its Beam... Notes on Nabokov's Poetry and Verse“]. Averin B.V., editor. V.V. Nabokov: pro et contra, vol. 2. St. Petersburg, RHGI Publ., 200I, pp. 213-226. (In Russ.) XV v." ["Medieval Alexander Romance in Russian Literature of the $15^{\text {th }}$ Century"]. Botvinnik, M.N., and Lur'e, Ja.S., and Tvorogov, O.V., editors. Aleksandriia. Roman ob Aleksandre Makedonskom po russkoi rukopisi XV v. [The Alexander Romance in Russian $15^{\text {th }}$ Century Manuscript]. Moscow, Leningrad, Nauka Publ., I966, pp. I45-I68. (In Russ.)

23 Orshanskii, Il. "Talmudicheskie skazaniia ob Aleksandre Makedonskom” ["Talmudic Tales about Alexander of Macedon"]. Sbornik statei po evreiskoi istorii i literature, izdavaemyi Obshhestvom dlia rasprostraneniia prosveshheniia mezhdu evreiami $v$ Rossii 
[Collected Papers on Jewish History and Literature], vol. I. St. Petersburg, I866, pp. I-I6. (In Russ.)

24 Panova, L.G. "Igry s Briusovym: Aleksandr Velikii v tvorchestve Kuzmina” ["Plays with Briusov: Alexander the Great in Kuzmin's Works"]. Novoe literaturnoe obozrenie, no. 2 (78), 2006, pp. 222-240. (In Russ.)

25 Panchenko, A.A. “'Spasibo za pochku!': Vlast' i potreblenie v organ theft legends” [“'Thank You for the Kidney!': Power and Consumption in the Organ Theft Legends”]. Etnograficheskoe obozrenie, no. 6, 2014, pp. 22-42. (In Russ.)

26 Pen'kovskii, A.B. Zagadki pushkinskogo teksta i slovaria: Opyt filologicheskoi germenevtiki [Mysteries of Pushkin's Text and Vocabulary: Studies on Philological Hermeneutics]. Moscow, Iazyki slavianskih kul'tur Publ., 2005. 3I4 p. (In Russ.)

27 Sultanbekov, M. Poemy Abaia: avtoref. dis. ... kand. filolog. nauk [Abay's Poetry: PhD Thesis, Summary]. Alma-Ata, I970. I6 p. (In Russ.)

28 Haber, E. “'Podvig” Nabokova i volshebnaia skazka” ["Nabokov's Glory and the Fairy Tale”]. Averin B.V., editor. V.V. Nabokov: pro et contra, vol. 2. St. Petersburg, RHGI Publ., 200I, pp. 716-729. (In Russ.)

29 Etkind, A.M. Vnutrenniaia kolonizaciia. Imperskii opyt Rossii [Internal Colonization: Russia's Imperial Experience]. Moscow, Novoe literaturnoe obozrenie Publ., 2013. 448 p. (In Russ.)

30 Amitay, Ory. “Alexander in Bavli Tamid: In Search for a Meaning." The Alexander Romance in Persia and the East. Ed. by Richard Stoneman et al. Groningen, Barkhuis Publishing, 20I2, pp. 349-368. (In English)

3I Dönitz, Saskia. "Alexander the Great in Medieval Hebrew Traditions." A Companion to Alexander Literature in the Middle Ages. Ed. by Z. David Zuwiyya. Leiden, Brill, 2oII, pp. 2I-40. (In English)

32 Elliott, John H. Beware the Evil Eye: the Evil Eye in the Bible and the Ancient World. Vol. 3: The Bible and Related Sources. Eugene, OR, Pickwick Publications, 20I6. 360 p. (In English)

33 Harf-Lancner, Laurence. "Medieval French Alexander Romances." A Companion to Alexander Literature in the Middle Ages. Ed. by Z. David Zuwiyya. Leiden, Brill, 20II, pp. 20I-230. (In English)

34 Johnson, D. Barton. “'L'Inconnue de la Seine' and Nabokov's Naiads.” Comparative Literature, vol. 44, no. 3, I992, pp. 225-248. (In English)

35 Leving, Yuri. Keys to The Gift: A Guide to Nabokov's Novel. Boston, Academic Studies Press, 20II. 534 p. (In English)

36 Morosini, Roberta. The Alexander Romance in Italy 'A Companion to Alexander Literature in the Middle Ages'. Ed. by Z. David Zuwiyya. Leiden, Brill, 20II, pp. 329-364. (In English)

37 Ronen, Omri. "Nine Notes to 'The Gift'.” The Nabokovian, vol. 44, spring 2000, pp. 20-26. (In English) 
38 Stoneman, Richard. Primary Sources from the Classical and Early Medieval Periods 'A Companion to Alexander Literature in the Middle Ages'. Ed. by Z. David Zuwiyya. Leiden, Brill, 20II, pp. I-20. (In English)

39 van Bekkum, Wout Jacgues. "Alexander the Great in Medieval Hebrew Literature." Journal of the Warburg and Courtauld Institutes, vol. 49, 1986, pp. 218-226. (In English)

40 Wazana, Nili. “A Case of the Evil Eye: Qohelet 4: 4-8.” Journal of Biblical Literature, I26/4, 2007, pp. 685-702. (In English)

4I Zimmer, Dieter E., and Hartmann, Sabine. “The Amazing Music of Truth: Nabokov's Sources for Godunov's Central Asian Travels in The Gift.” Nabokov Studies, vol. 7, 2002/2003, pp. 33-74. (In English) 